\title{
Earliest detection of oral cancer using non-invasive brush biopsy including DNA-image-cytometry: Report on four cases
}

\author{
Torsten W. Remmerbach ${ }^{\mathrm{a}, *, * *}$, Horst Weidenbach ${ }^{\mathrm{b}}$, Alexander Hemprich $^{\mathrm{a}}$ and Alfred Böcking ${ }^{\mathrm{c}}$ \\ ${ }^{a}$ Department of Oral, Maxillofacial and Facial Plastic Surgery, University of Leipzig, Nürnberger Straße 57, \\ D-04103 Leipzig, Germany \\ ${ }^{\mathrm{b}}$ Institute of Pathology, University of Leipzig, Liebigstraße 26, D-04103 Leipzig, Germany \\ c Institute of Cytopathology, Heinrich Heine University, Moorenstraße 5, D-40225 Düsseldorf, Germany
}

Received 6 February 2003

Accepted 20 May 2003

\begin{abstract}
Objective: We describe four patients presenting early oral cancers, detected cytologically on non-invasive brush biopsies including DNA-image cytometry as an adjunctive method before histology on scalpel biopsies confirmed the evidence of malignancy.

Methods: Brush biopsies were performed and smears thereof investigated cytologically. After Feulgen restaining, DNAmeasurements were performed using a DNA-Image-Cytometer.

Case reports: Oral squamous cell carcinomas were diagnosed cytologically in macroscopically suspicious lesions and malignancy confirmed by DNA-cytometry. The initially performed scalpel biopsies did neither supply evidence of oral cancer nor of severe dysplasia. After at least one to 15 months the occurrence of cancer was finally proven histologically on a second scalpel biopsy each (three microinvasive and one in situ carcinoma).

Conclusion: Non-invasive brush biopsies are a suitable instrument for early cytologic detection of cancer of the mouth. DNAimage-cytometry, as an adjunctive method, can be used to confirm the cytologic diagnosis or suspicion of cancer in patients with doubtful lesions (dysplasias). DNA-aneuploidy is a marker for (prospective) malignancy in smears of the oral cavity, which may detect malignancy months prior to histology. In future this method could be used as a mass screening tool in dentists practise.

Colour figures can be viewed on http://www.esacp.org/acp/2003/25-4/remmerbach.htm.
\end{abstract}

Keywords: Brush biopsy, oral cancer, DNA-image-cytometry, mass screening tool

\footnotetext{
${ }^{*}$ Corresponding author: Dr. Torsten W. Remmerbach. Tel.: +49 (0) 3419721100; Fax: +49 (0) 3419721109; E-mail: remmt @ medizin.uni-leipzig.de.

${ }^{* *}$ Dr. Remmerbach is oral surgeon, Department of Oral, Maxillofacial and Facial Plastic Surgery; Dr. Weidenbach is pathologist, Institute of Pathology; Dr. Dr. Hemprich is Professor of Oral, Maxillofacial and Facial Plastic Surgery and Head, Department of Oral, Maxillofacial and Plastic Surgery; Dr. Böcking is Professor of Pathology and Head, Institute of Cytopathology.
}

\section{Introduction}

Squamous cell carcinomas of the oral cavity (OSCCs) are among the ten most common cancers in the world, accounting for 3-5\% of all malignancies [16]. In 1993 in Germany, approximately about 3100 new cases in males and 1000 in females were encountered [13]. The prognosis for many of these patients is devastating. Up to $50 \%$ of the patients will die in the first five years after the cancer has been diagnosed [8]. For patients, lack of early and correct identification 
of carcinomas in the oral cavity may result in unnecessary inadequate further examinations and decreased survival probability. Poor education of dentists in this field often delays necessary therapy with inevitable progression of the tumour. Not only clinicians fail diagnosing cancer in early stages, but also histopathologists sometimes miss preinvasive oral cancer evaluating scalpel biopsies and state dysplasias or reactive lesions instead [5].

\section{Material and methods}

Alcohol-fixed smears from oral brushings were stained according to Papanicolaou (Pap). DNA-cytometry was performed secondarily on Pap-stained routine slides after restaining according to Feulgen. After postfixation with $10 \%$ buffered formalin and staining with pararosaniline, measurements were performed using an AutoCyte QUIC pathology workstation (TriPath, Burlington NC, USA and Carl Zeiss, Jena, Germany). The normal $2 \mathrm{c}$ reference value was established measuring 30 normal epithelial cells as an internal reference (mean IOD value). Three hundred abnormal or atypical epithelial cells were measured at random. We assumed aneuploidy either in the presence of an abnormal stemline (modal value $\langle 1.80 \mathrm{c}\rangle 2.20 \mathrm{c}$ or $\langle 3.60\rangle 4.40$ or $\langle 7.20\rangle 8.80 \mathrm{c}$ ), or if cells $>9 \mathrm{cEE}$ (9c Exceeding Events) occurred. The performance standards of the ESACP consensus reports on diagnostic DNA image cytometry were obeyed $[3,4,6,7]$.

\section{Presentation of cases}

\subsection{Case A}

A 47-year-old white male presented a painful, softish ulcer (4 $\mathrm{mm}$ in diameter) with white speckled border on the right side of the tongue (Fig. 1). The cyto-

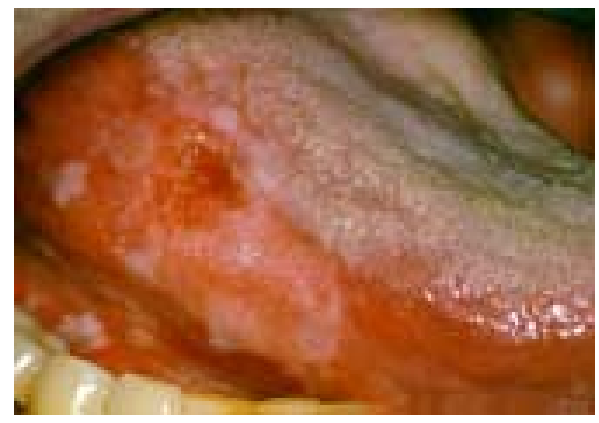

Fig. 1. Clinical view of the tongue from patient $A$ at his first visit in our clinic. This figure can be viewed on http://www.esacp.org/acp/ 2003/25-4/remmerbach.htm logic examination of a brush biopsy unequivocally revealed cells from a squamous cell carcinoma (Fig. 2). DNA-cytometry showed a stemline at $4.31 \mathrm{c}$ and seven cells greater 9c (Fig. 3). Two scalpel biopsies with histological examination resulted in the diagnosis of a florid ulcer with pseudoepithelimatous hyperplasia without any signs of malignancy. Seven months later, the patient was in close meshed recall, total excision of the lesion confirmed the presence of a microinvasive squamous cell carcinoma of the tongue. Thus DNA-

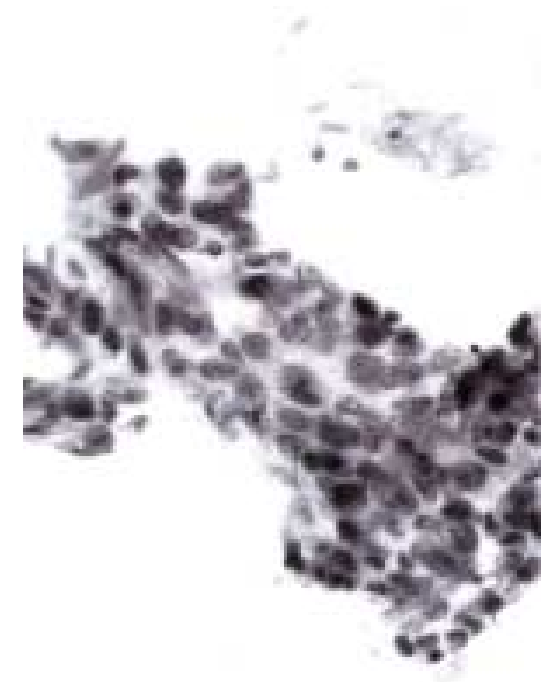

Fig. 2. Cluster of exfoliated coherent cells from an early squamous cell carcinoma of the tongue revealing hyperchromatic small but polymorphic nuclei with enlarged nuclear-cytoplasmic ratio and prominent nucleoli. Patient A. Primary magnification $630 \times$.

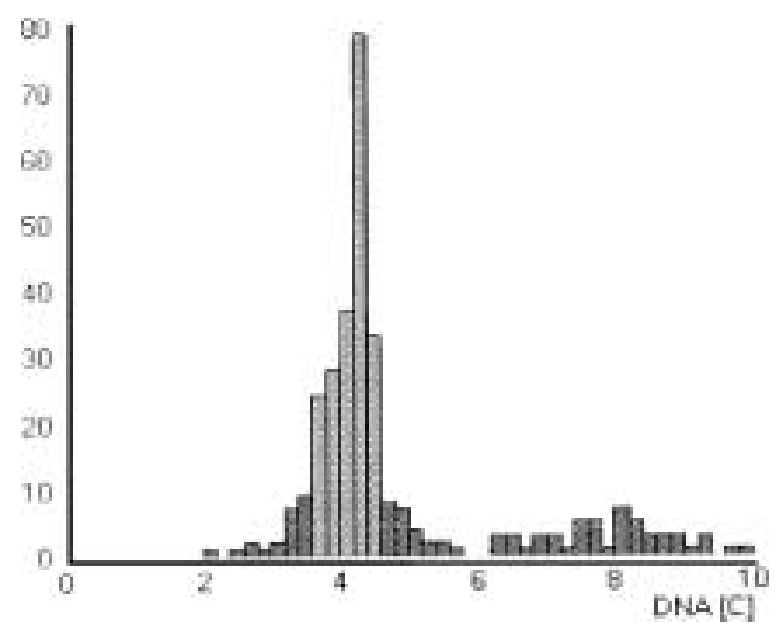

Fig. 3. DNA-histogram of a smear from a squamous cell carcinoma of the tongue (patient A). Different aspects of DNA-aneuploidy can be detected: abnormal stemline $4.31 \mathrm{c}$ and 7 cells greater $9 \mathrm{c}(9 \mathrm{cEE})$. 


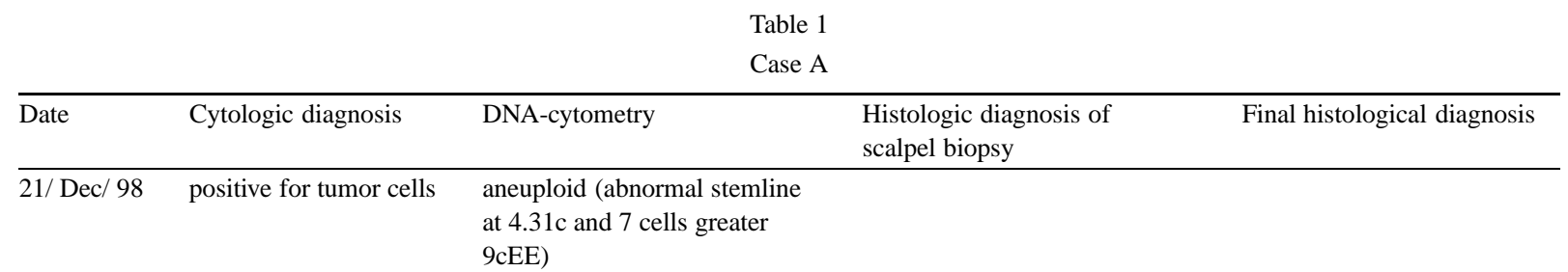

6/ Jan/ 99

floride ulcus, no signs of malignancy

23/ Jul/ 99

oral squamous cell carcinoma (G2)

Elapsed time between first cytologic/DNA-cytometric cancer diagnosis and histological verification: 7 months

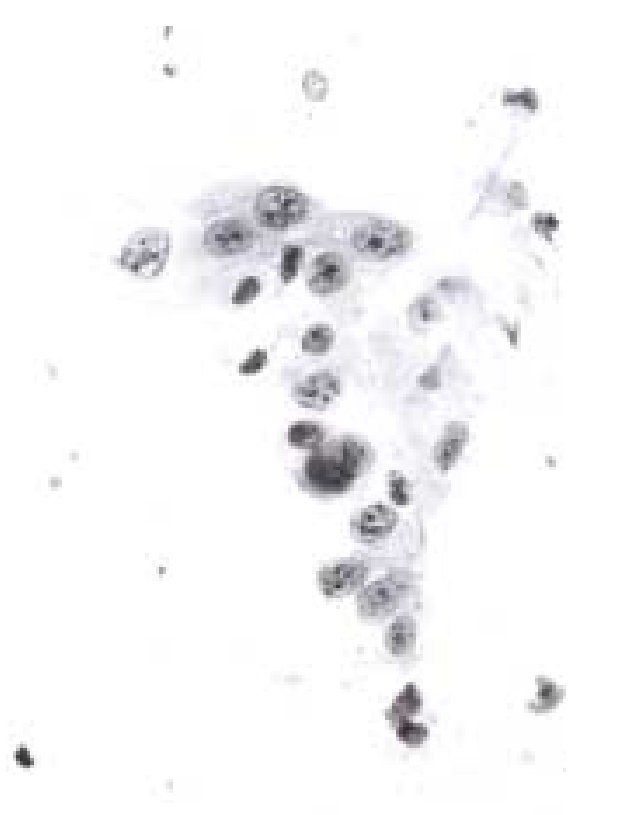

Fig. 4. Atypical oral musoca cells, suspicious for squamous cell carcinoma with enlarged and slightly polymorphic nuclei containing prominent nucleoli and coarse chromatin. Patient B. Primary magnification $630 \times$.

image cytometry (DNA-ICM) established the diagnosis of malignancy seven months prior to biopsy histology (Table 1).

\subsection{Case B}

A 74-year-old male diagnosed in 1997 with oral squamous cell carcinoma (OSCC), the altered area was the left mandible in region 33-36. This was removed by resection. Follow up reviews were performed at regular intervals. In May 2000 a leukoplakia occurred in this area and was checked cytologically on a brush biopsy. The smears were suspicious for malignant cells. DNA-cytometry could not be performed,

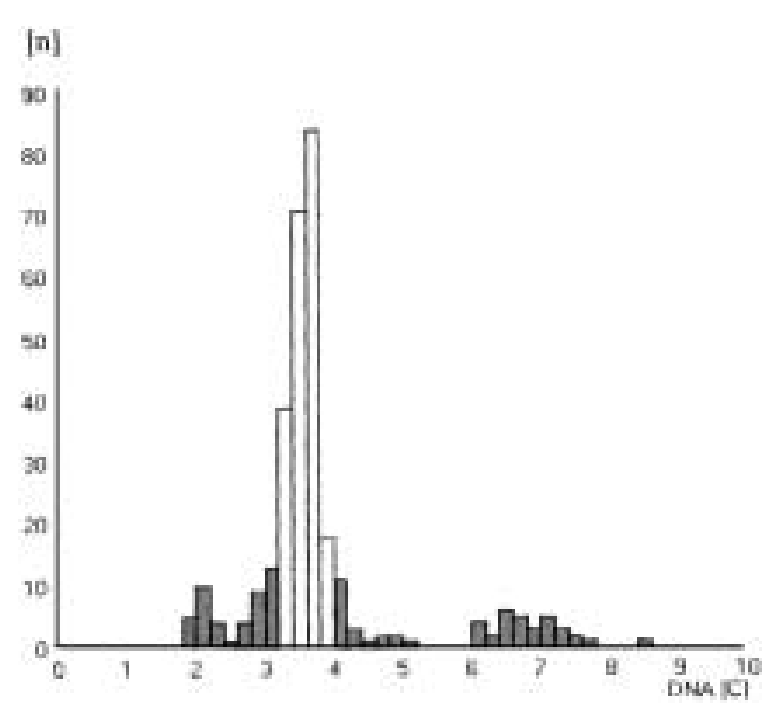

Fig. 5. DNA-histogram of a smear from a squamous cell carcinoma of the alveolar ridge from patient B. One aspect of DNA-aneuploidy can be detected: abnormal stemlines at $3.6 \mathrm{c}$ and $7.2 \mathrm{c}$.

because of insufficient number of cells. Scalpel biopsies carried out three times showed pseudoepithelimatous hyperplasias. Three months later, the brush biopsy was repeated. The cytological diagnosis was doubtful for tumor cells (Fig. 4), but DNA-cytometry revealed aneuploidy with abnormal stemlines at $3.6 \mathrm{c}$ and 7.2c (Fig. 5). Total excision of this area with histologic examination definitely confirmed microinvasive OSCC, five months after first performed brush biopsy with strong suspicion for tumor cells. The delay from first brush biopsy until histological confirmation of an OSCC thus was five months (Table 2).

\subsection{Case C}

A 67-year-old male, diagnosed with oral cancer in 1994. After total excision of the tumor including a suprahyoid lymph node dissection, the patient was in 


\begin{tabular}{|c|c|c|c|c|}
\hline Date & Cytologic diagnosis & DNA-cytometry & $\begin{array}{l}\text { Histologic diagnosis of } \\
\text { scalpel biopsy }\end{array}$ & Final histological diagnosis \\
\hline 26/ May/ 00 & suspicious for tumor cells & & & \\
\hline 6/ Jun/ 00 & & & $\begin{array}{l}\text { pseudoepitheliomatous } \\
\text { hyperplasia }\end{array}$ & \\
\hline 4/ Sep/ 00 & doubtful for tumor cells & $\begin{array}{l}\text { aneuploid (abnormal } \\
\text { stemline at } 3.6 \mathrm{c} \text { and } \\
7.2 \mathrm{c} \text { cells) }\end{array}$ & & \\
\hline
\end{tabular}

$24 / \mathrm{Oct} / 00$

microinvasive oral squamous cell carcinoma $(\mathrm{G} 2)$

Elapsed time between first cytologic/DNA-cytometric cancer diagnosis and histological verification: 5 months

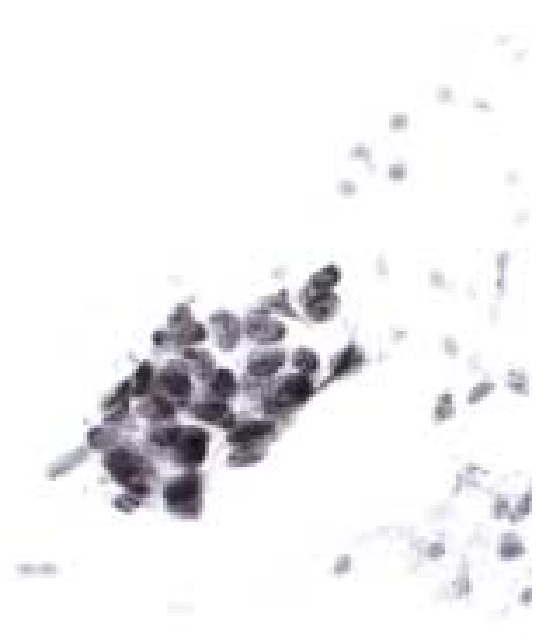

Fig. 6. Abnormal cells from an oral squamous cell carcinoma revealing nuclear polymorphism, chromatin clumping, nucleoli and increased nuclear-cytoplasmic ratio. Patient C. Original magnification $630 \times$.

closed meshed recall. In January 1999 a small, soft and white-patched homogenous area of $3 \mathrm{~mm}$ in diameter appeared on the arcus palatoglossus of the right side. The performed brush biopsy unequivocally showed tumor cells of an OSCC (Fig. 6), DNA-cytometry revealed an aneuploid stemline at $3.1 \mathrm{c}$ and 24 cells greater 9c (Fig. 7). At the same time an ostentatious supraclavicular lymph node on the right side appeared and a conventional neck dissection was performed (histologically a metastasis of an OSCC was proven). The clinicans started from the principle, that the suspicious area in the mouth was not the reason for this metastasis and from clinical view seemingly in back formation. Two months later scalpel biopsy from the above described area with histological examination showed no atypia or dysplasia. Five months later a second brush biopsy was suspicious for tumour cells but the smears were technically insufficient for DNA measurement.

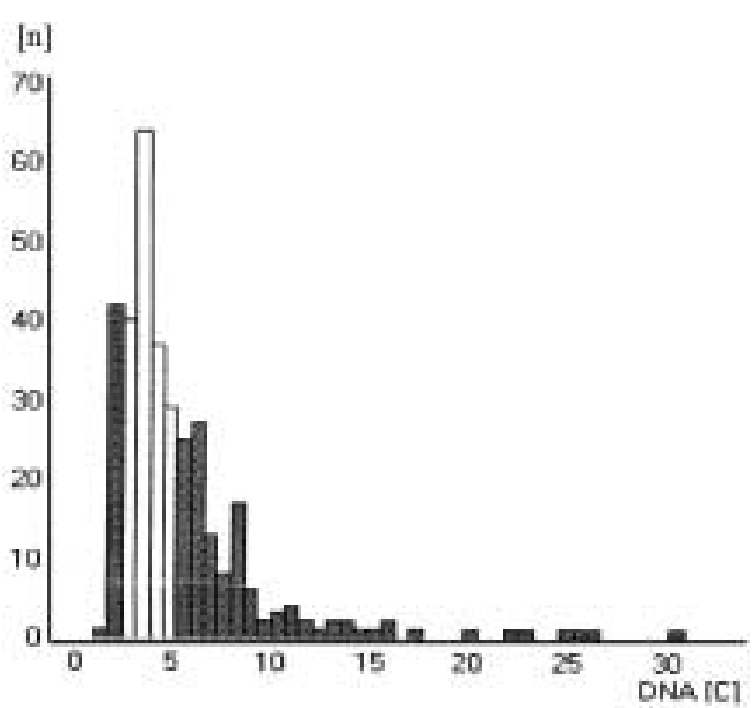

Fig. 7. DNA-histogram of a smear from a squamous cell carcinoma of the arcus palatoglossus (patient C). Different aspects of DNA-aneuploidy can be detected: abnormal stemline at $3.1 \mathrm{c}$ and 24 cells greater 9c $(9 \mathrm{cEE})$.

Four months later the third brush biopsy was doubtful for tumor cells and DNA-cytometry revealed DNAaneuploidy with an abnormal stemline at 3.34c and four cells greater 9c. After six weeks (15 month after first performed brush biopsy) total excision of this area revealed a leukoplakia with severe dysplasia. Three months later, the patient was diagnosed with a second squamous cell carcinoma of the oesophagus with metastases to the lung. Thus DNA-ICM established the diagnosis of malignancy five months prior to histology diagnosis (Table 3 ).

\subsection{Case D}

An 82-year-old white male presented a widespread verrucous leukoplakia of the sinistral pouch (Fig. 8) 


\begin{tabular}{|c|c|c|c|c|}
\hline$\overline{\text { Date }}$ & Cytologic diagnosis & DNA-cytometry & $\begin{array}{l}\text { Histologic diagnosis of } \\
\text { scalpel biopsy }\end{array}$ & Final histological diagnosis \\
\hline 18/ Jan/ 99 & positive for tumor cells & $\begin{array}{l}\text { aneuploid (abnormal } \\
\text { stemline at } 3.1 \mathrm{c} \text { and } 24 \\
\text { cells greater 9cEE) }\end{array}$ & & \\
\hline 26/ May/ 99 & & & $\begin{array}{l}\text { supraclavicular lymph node } \\
\text { metastasis of a an oral } \\
\text { squamous cell carcinoma }\end{array}$ & \\
\hline 20/ Jul/ 99 & & & $\begin{array}{l}\text { no dysplasia, no atypia, no } \\
\text { signs of malignancy }\end{array}$ & \\
\hline 1/ Oct/ 99 & suspicios for tumor cells & $\begin{array}{l}\text { not enough cells for } \\
\text { measurement }\end{array}$ & & \\
\hline 25/ Feb/ 00 & doubtful for tumor cells, c.i.s. & $\begin{array}{l}\text { aneuploid (abnormal } \\
\text { stemline at } 3.34 \mathrm{c} \text { and } 4 \\
\text { cells greater 9cEE) }\end{array}$ & & \\
\hline 4/ Apr/ 00 & & & & $\begin{array}{l}\text { leukoplakia with severe } \\
\text { dysplasia }\end{array}$ \\
\hline $28 / \mathrm{Jul} / 00$ & & & & $\begin{array}{l}\text { squamous cell carcinoma } \\
\text { (G3) oesophagus }\end{array}$ \\
\hline
\end{tabular}

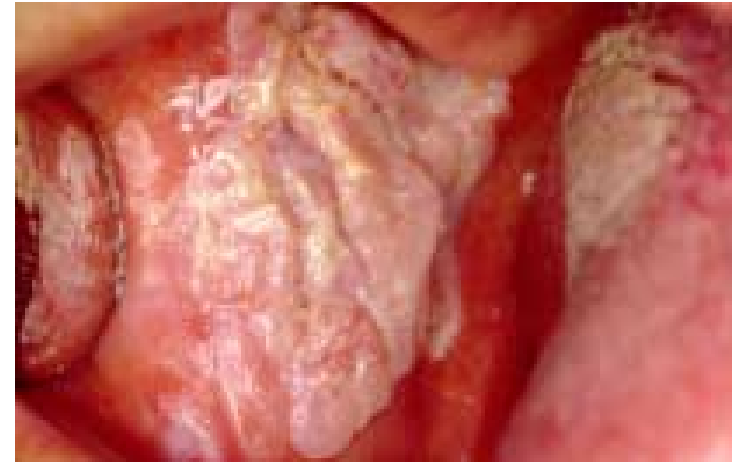

Fig. 8. Clinical view of a verrucous leukoplakia of the sinister pouch from patient $\mathrm{D}$ at his first visit in our clinic. This figure can be viewed on http://www.esacp.org/acp/2003/25-4/remmerbach.htm.

with an unknown progression and medical history. A brush biopsy was performed. No abnormal or atypical cells were detected; the total excision with histological examination confirmed the cytological result. After five months, a leukoplakia reappeared and two brush biopsies were performed: one in the proximal part and one in the distal part of the left pouch. The outcome of the cytological examination of the proximal smears was suspicious for cancer cells, the distal part was positive for tumour cells of an OSCC (Fig. 9). DNA-image cytometry showed aneuploidy with multiple abnormal stemlines at $2.5 \mathrm{c}, 3.38 \mathrm{c}, 3 \mathrm{c}, 4 \mathrm{c}$ and $5 \mathrm{c}$ (Fig. 10). The outcome of thorough examination of scalpel biopsies revealed no evidence of tumour cells.

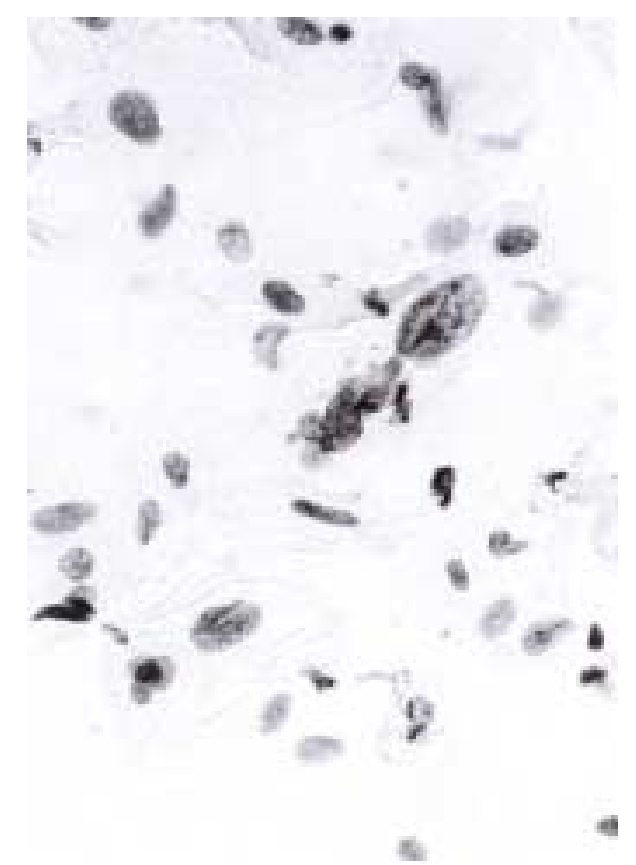

Fig. 9. Few abnormal cells from a squamous cell carcinoma showing coarse chromatin and prominent nucleoli in polymorphic nuclei of variable size. Patient D. Original magnification $630 \times$.

After one month the scalpel biopsy was repeated and the occurrence of a microinvasive squamous cell carcinoma was proven histologically. Between the first brush biopsy and the histological conformation of an OSCC seven weeks had elapsed (Table 4). 


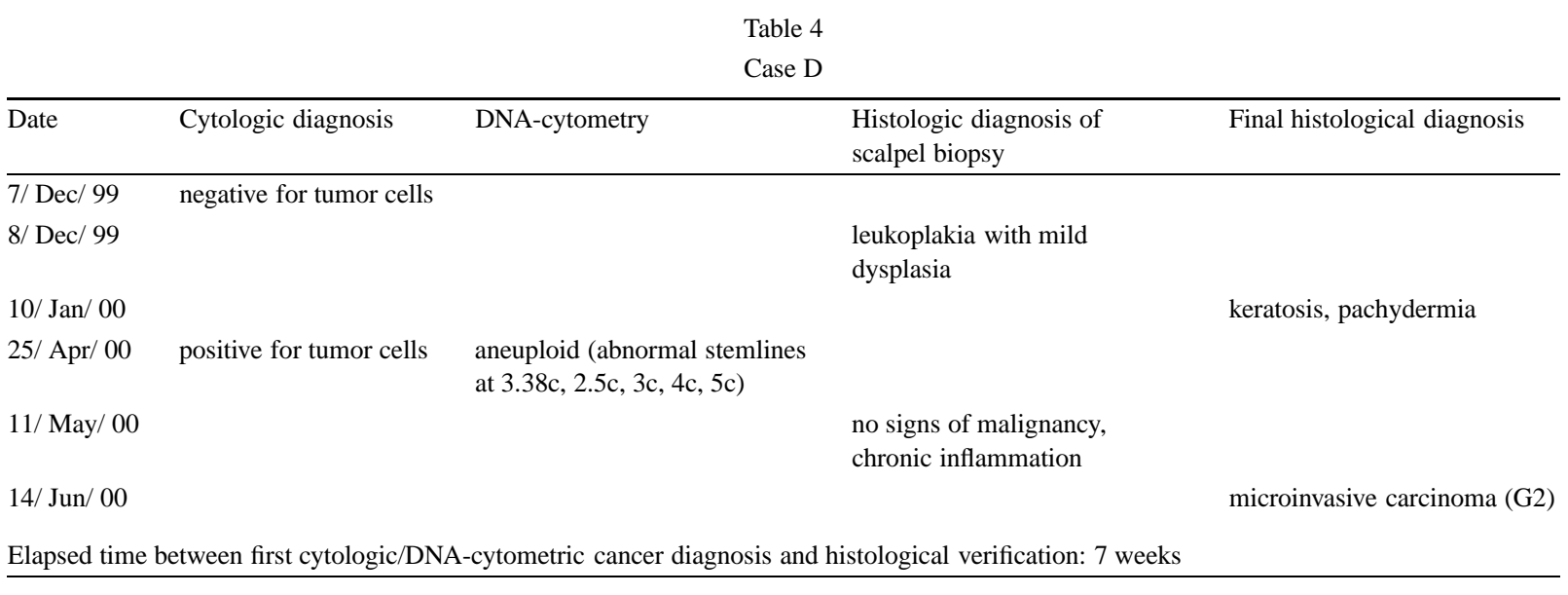

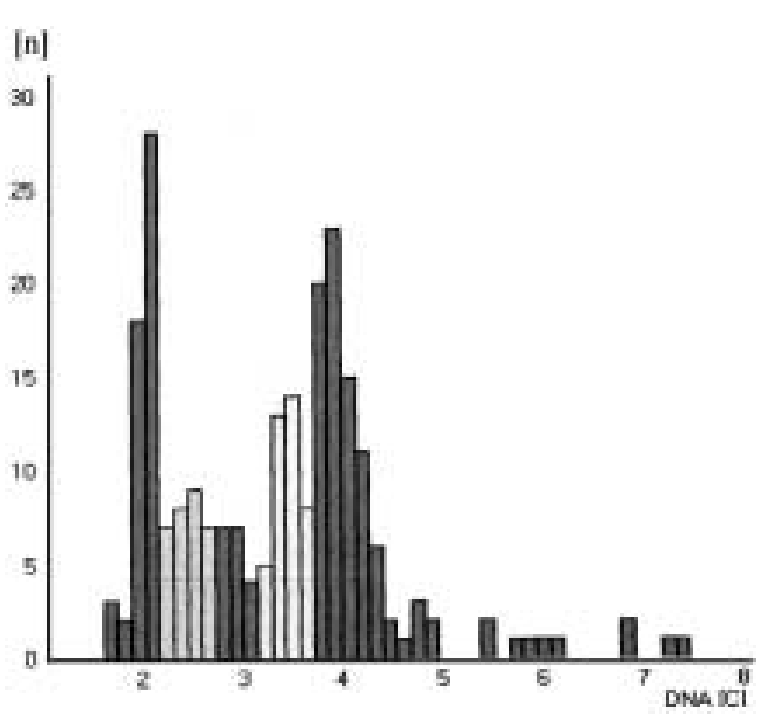

Fig. 10. DNA-histogram of a smear from a squamous cell carcinoma of the buccal mucosa (patient D). One aspect of DNA-aneuploidy can be detected: abnormal stemlines at $2.5 \mathrm{c}, 3.38 \mathrm{c}, 3 \mathrm{c}$ and $4 \mathrm{c}$.

\section{Discussion}

Colour figures can be viewed on http://www.esacp. org/acp/2003/25-4/remmerbach.htm

There is a need to promote the early diagnosis of oral cancers in order to reduce its unacceptably high morbidity and mortality. Sudbø et al. (2001) [15] have shown in a retrospective study that the DNA content in cells of oral dysplasias histologically diagnosed on scalpel biopsies was able to predict the occurrence of oral carcinoma later up to five years before their clinical appearance. Of 150 patients, 25 (17 percent) had DNA aneuploid lesions at the time of the initial diagnosis. Disease-free survival was assessed in relation to DNA-histogram type and histologic grade or dys- plasia. Carcinomas developed in 21 of the 25 patients with DNA-aneuploid lesions within five years, yielding a positive predictive value of 84 percent. Our four cases reported here represent the clinical equivalent to this study.

Our group has demonstrated in a previous prospective study, that exfoliative cytology performed on oral brushings can help dentists to decide, if a given oral lesion is malignant or not. Sensitivity of our cytological diagnosis on oral smears for the detection of cancer cells was $94.6 \%$, specificity $99.5 \%$, positive predictive value $98.1 \%$ and negative predictive value 98.5\%. DNA-aneuploidy was assumed if abnormal DNA-stemlines or cells with DNA-content greater 9c were observed. On this basis the prevalence of DNAaneuploidy in smears of oral squamous cell carcinomas in situ or invasive carcinomas was $96.4 \%$. Sensitivity of DNA-aneuploidy in oral smears for the detection of cancer cells was $96.4 \%$, specificity $100 \%$, positive predictive value $100 \%$ and negative $99.0 \%$. The combination of both techniques increased the sensitivity to $98.2 \%$, specificity to $100 \%$, positive predictive value to $100 \%$ and negative to $99.5 \%$ [12].

In the cases reported here, cytology alone detected carcinoma cells in three of four cases. DNA cytometry revealed aneuploidy as a marker for neoplasia in all four cases of early cancer. Yet the clinicians doubted these diagnoses, as they were not consistent with the results of the histological examination of the scalpel biopsies up to this point. False negative results occasionally occur in histological examinations, but they are very rarely reported in the literature [5].

False negative cancer diagnoses have similar reasons in histology and cytology: (1) Sampling errors. Surgical biopsies may be taken at non-representative sites for histology, as well as brush biopsies and mean 
for cytology. (2) Screening errors: Fixed and paraffinembedded tissues may not sufficiently be worked up as serial sections in histology and smears may not be screened thoroughly by cytologists. (3) Interpretation errors: Due to subjectivity of interpretation of microscopical images of tissues and cells interobserver variations in histological and cytological diagnoses occur. (4) Furthermore epithelial dysplasias and borderline lesions represent morphological alterations which are suspicious for malignancy but do not represent sufficient evidence for its definite diagnosis. The latter situation offers the opportunity for adjuvant methods to identify (prospective) malignancy earlier than subjective interpretation of histological or cytological images. This is the case for DNA-cytometry and AgNORanalysis [10,11].

Furthermore data from the literature show insufficient inter- and intra-individual reproducibility of histological grading epithelial dysplasias (e.g., oral cavity [1,2], squamous intraepithelial lesions [17] and cervical abnormalities [14]) and problems in unequivocally identifying carcinoma in situ.

DNA-image-cytometry was able to confirm the malignant nature of suspicious abnormal epithelial cells. Thus, in one case the initial cytological diagnosis "doubtful" could be changed to "definitely malignant, consistent with a squamous cell carcinoma". In three cases DNA cytometry confirmed the cytological report stating unequivocal squamous malignant cells. Thus this method should be applied for the purpose of quality assurance of cytologically suspicious or doubtful oral squamous lesions.

In most cases clinicans are responsible for false negative cancer diagnosis (sampling error), due to nonrepresentable acquisition of cells or tissues. In gynaecological and pulmonary cytology this error accounts for about $80 \%$ of false negative diagnoses. Errors due to microscopically overlooked tumour cells by cytopathologists are less frequent than due to sampling errors [9]. Most likely, in two of our cases (C and D) geographic errors occurred performing scalpel biopsies while brush biopsies revealed cancer diagnoses despite this source of error. This may be explained by the larger area from which brushings sample cells compared with a limited mucosal area from which a biopsy is taken. Mostly oral surgeons do not excise suspicious lesions in toto to establish its nature at first. Thus, they have to decide, which part of the lesion represents the area of strong suspicion of malignancy. This disadvantage is minimized using brush biopsy, because it is possible to brush all areas of the relevant lesions.
We believe that the initial tumour negative histological diagnoses of case A and B might have been errors in microscopical interpretation although it still has to be proven that pseudoepitheliomatous hyperplasia without signs of malignancy in other cases does not reveal DNA-aneuploidy.

The malignant transformation at the beginning of carcinogenesis affects only few cells long before small parts of the tissue were involved. Thus cytologic examination should be a suitable method to elucidate the dignity of suspicious oral lesions earlier than histology. In cases of early cancer diagnosis at least some hundred abnormal cells are required, so that, for example, DNA-image-cytometry may identify signs of aneuploidy to support the cytological cancer diagnosis of cancer.

We conclude that the application of DNA-image cytometry increases the diagnostic accuracy of brush biopsies of the oral cavity. This adjuvant method is able to identify malignant cells in brush biopsies via detection of abnormal DNA stemlines or atypically high single DNA-values ( $>9 \mathrm{c})$. The advantages of brush biopsies are obvious: brushings of all visible oral lesions, even if they are clinically not considered as suspicious for cancer, are an easily practicable, cheap, noninvasive, largely painless, safe and accurate screening method for detection of oral precancerous lesions (dysplasias), carcinomas in situ or invasive squamous cell carcinoma in all stages. We conclude that DNA-image cytometry is a very sensitive, highly specific and objective adjuvant tool for the earliest identification of neoplastic epithelial cells in oral smears.

\section{Acknowledgements}

We thank Dr. C. Huppa, King's College Hospital, London, for his critical review of the manuscript.

\section{References}

[1] L.M. Abbey, G.E. Kaugars, J.C. Gunsolley, J.C. Burns, D.G. Page, J.A. Svirsky, E. Eisenberg, D.J. Krutchkoff and M. Cushing, Intraexaminer and interexaminer reliability in the diagnosis of oral epithelial dysplasia, Oral Surg. Oral Med. Oral Pathol. Oral Radiol. Endod. 80 (1995), 188-191.

[2] L.M. Abbey, G.E. Kaugars, J.C. Gunsolley, J.C. Burns, D.G. Page, J.A. Svirsky, E. Eisenberg and D.J. Krutchkoff, The effect of clinical information on the histopathologic diagnosis of oral epithelial dysplasia, Oral Surg. Oral Med. Oral Pathol. Oral Radiol. Endod. 85 (1998), 74-77. 
[3] A. Böcking, F. Giroud and A. Reith, Consensus report of the ESACP task force on standardization of diagnostic DNA image cytometry. European Society for Analytical Cellular Pathology, Anal. Cell. Pathol. 8 (1995), 67-74.

[4] F. Giroud, G. Haroske, A. Reith and A. Böcking, 1997 ESACP consensus report on diagnostic DNA image cytometry. Part II: Specific recommendations for quality assurance. European Society for Analytical Cellular Pathology, Anal. Cell. Pathol. 17 (1998), 201-208.

[5] J. Guinta, I. Meyer and G. Shaklar, The accuracy of the oral biopsy in the diagnosis of cancer, Oral Surg. Oral Med. Oral Pathol. 28 (1969), 552-556.

[6] G. Haroske, J.P. Baak, H. Danielsen, F. Giroud, A. Gschwendtner, M. Oberholzer, A. Reith, P. Spieler and A. Böcking, Fourth updated ESACP consensus report on diagnostic DNA image cytometry, Anal. Cell. Pathol. 23 (2001), 89-95.

[7] G. Haroske, F. Giroud, A. Reith and A. Böcking, 1997 ESACP consensus report on diagnostic DNA image cytometry. Part I: basic considerations and recommendations for preparation, measurement and interpretation. European Society for Analytical Cellular Pathology, Anal. Cell. Pathol. 17 (1998), 189-200.

[8] H.P. Howald, M. Frenz and H. Pitz, Results from DÖSAK Observational Studies, in: Carcinoma of the Oral Cavity and Oropharynx, H.D. Pape, U. Ganzer and G. Schmitt, eds, Springer-Verlag, Berlin, Heidelberg, pp. 173-182.

[9] G. Möbius, Cytological early detection of cervical carcinoma: possibilities and limitations. Analysis of failures, J. Cancer Res. Clin. Oncol. 119 (1993), 513-521.

[10] N. Pomjanski, H. Motherby, B. Buckstegge, K. Knops, B.L. Rohn and A. Böcking, Early diagnosis of mesothelioma in serous effusions using AgNOR analysis, Anal. Quant. Cytol. Histol. 23(2) (2001), 151-160.
[11] T.W. Remmerbach, H. Weidenbach, C. Müller, A. Hemprich, N. Pomjanski, B. Buckstegge and A. Böcking, Diagnostic value of nucleolar organizer regions (AgNORs) in brush biopsies of precancerous and cancerous lesions of the oral cavity, Anal. Cell. Pathol. 25 (2003), 139-146.

[12] T.W. Remmerbach, H. Weidenbach, N. Pomjanski, K. Knops, S. Mathes, A. Hemprich and A. Böcking, Cytologic and DNAcytometric early diagnosis of oral cancer, Anal. Cell. Pathol. 22 (2001), 211-221.

[13] D. Schön, J. Bertz and H. Hoffmeister, Bevölkerungsbezogene Krebsregister der Bundesrepublik Deutschland. Robert Koch Institut Schriften, 2, 1995, 374.

[14] S.M. Selvaggi, Implications of low diagnostic reproducibility of cervical cytologic and histologic diagnoses, JAMA 285 (2001), 1506-1508.

[15] J. Sudbo, W. Kildal, B. Risberg, H.S. Koppang, H.E. Danielsen and A. Reith, DNA content as a prognostic marker in patients with oral leukoplakia, N. Engl. J. Med. 344 (2001), 1270-1278.

[16] J.C. Weir, W.D. Davenport and R.L. Skinner, A diagnostic and epidemiologic survey of 15,783 oral lesions, J. Am. Dent. Assoc. 115 (1987), 439-442.

[17] S.L. Woodhouse, J.F. Stastny, P.E. Styer, M. Kennedy, A.H. Praestgaard and D.D. Davey, Interobserver variability in subclassification of squamous intraepithelial lesions: Results of the College of American Pathologists Interlaboratory Comparison Program in Cervicovaginal Cytology, Arch. Pathol. Lab. Med. 123 (1999), 1079-1084. 


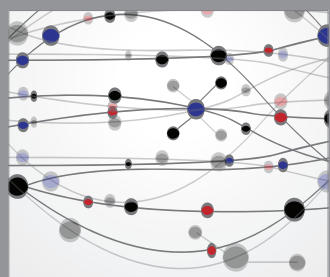

The Scientific World Journal
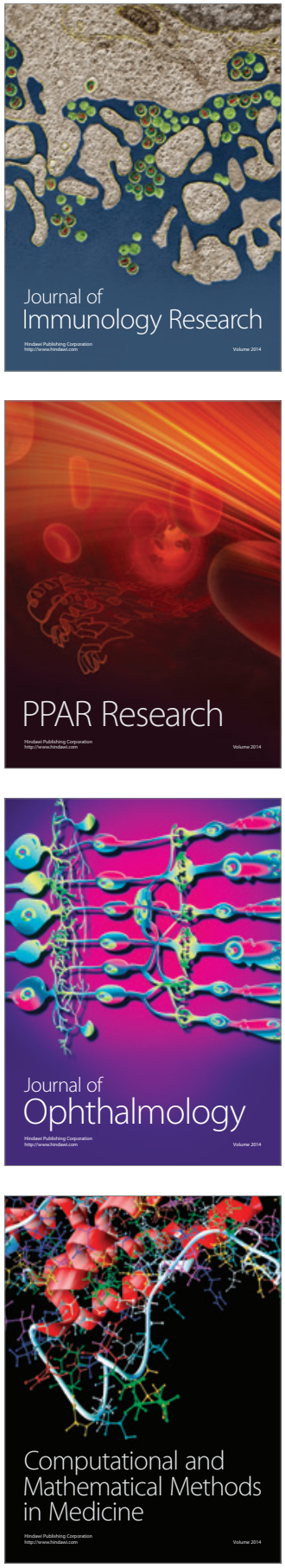

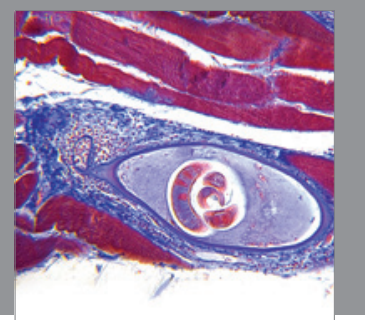

Gastroenterology

Research and Practice
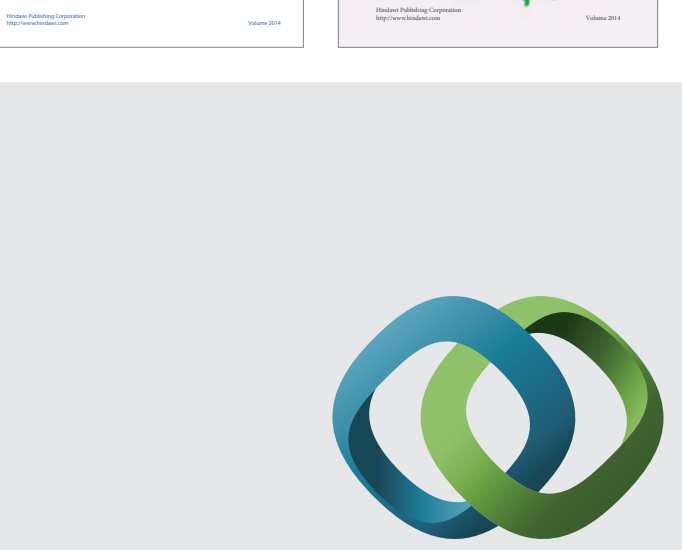

\section{Hindawi}

Submit your manuscripts at

http://www.hindawi.com
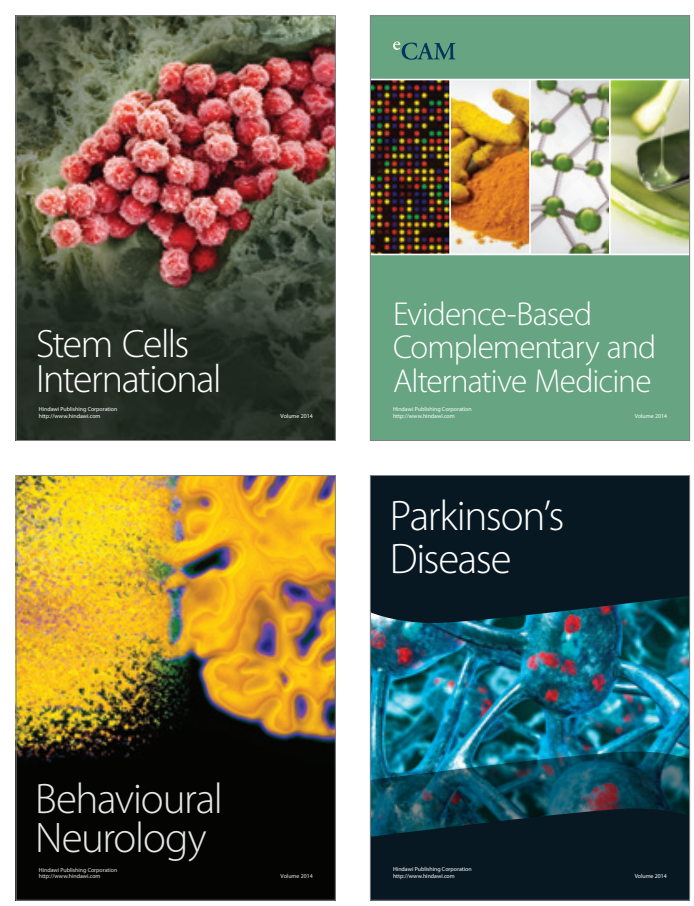

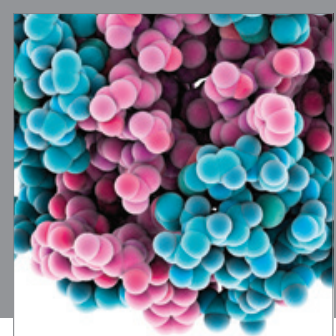

Journal of
Diabetes Research

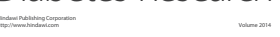

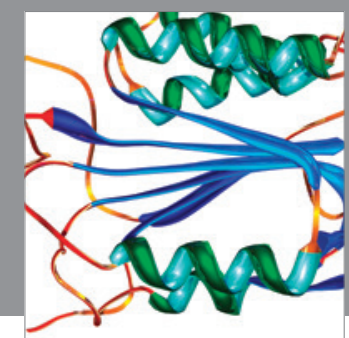

Disease Markers
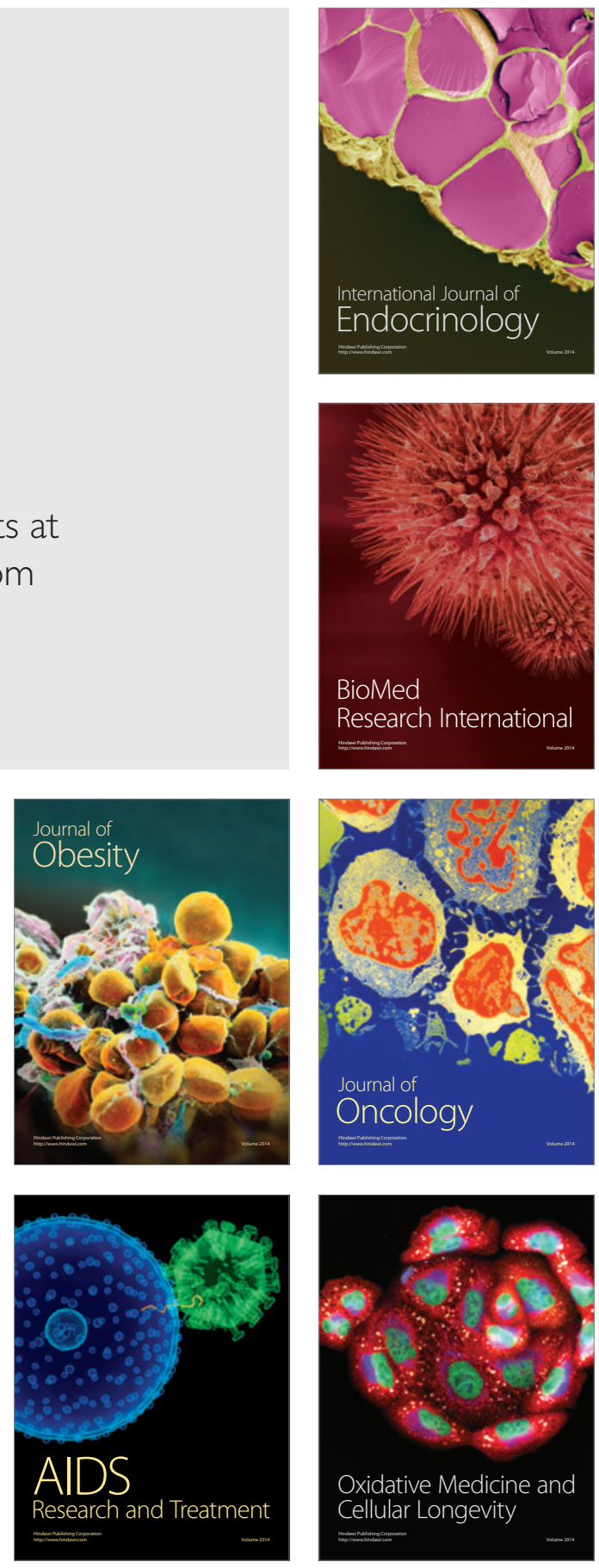